\section{Health department lays down the law on scientific misconduct}

Meredith Wadman, Washington

The US health department has issued comprehensive rules for handling scientific misconduct cases. And instead of kicking up a stink, most research organizations say that they find the regulations to their liking.

On 19 April, the Department of Health and Human Services issued a 27-page notice in the Federal Register, which publishes rules for US federal organizations. The department has narrowed its current definition of research misconduct and set out procedures for universities and government officials investigating allegations of scientific wrong-doing by federally funded researchers.

The regulations are probably the final chapter in a decade-long debate over what exactly constitutes scientific misconduct. And the department, which oversees most US biomedical research, has restricted the definition to "fabrication, falsification and plagiarism" - the offences that most researchers agree are egregious. The department has ditched the inclusion, in its current rules, of the ominous phrase "or other practices", which scientists criticized as vague and overly broad.

Last week's notice expands the definition of misconduct to say that it can occur during the review of grant proposals and journal articles. It also limits the role of whistle-blowers in investigations, stating that complainants may not participate except as witnesses.

"What they have created is a consistent, clean definition," says David Korn, senior vice-president for biomedical and health sciences research at the Association of American Medical Colleges. "Everybody understands what it means."

Not everyone shares Korn's cheerful perspective. "They are now saying a whistle-blower is merely someone who reports, and then stands aside," complains Vera Sharav, president of the Alliance for Human Research Protection, a New York-based patient advocacy group. "That is outrageous. Who else knows how to guide the investigation to evidence of the violations?"

Among other things, the revised policy requires complaints of misconduct to be filed within six years of the alleged event. The notice is open to public comment until 15 June, after which a final version will be published.

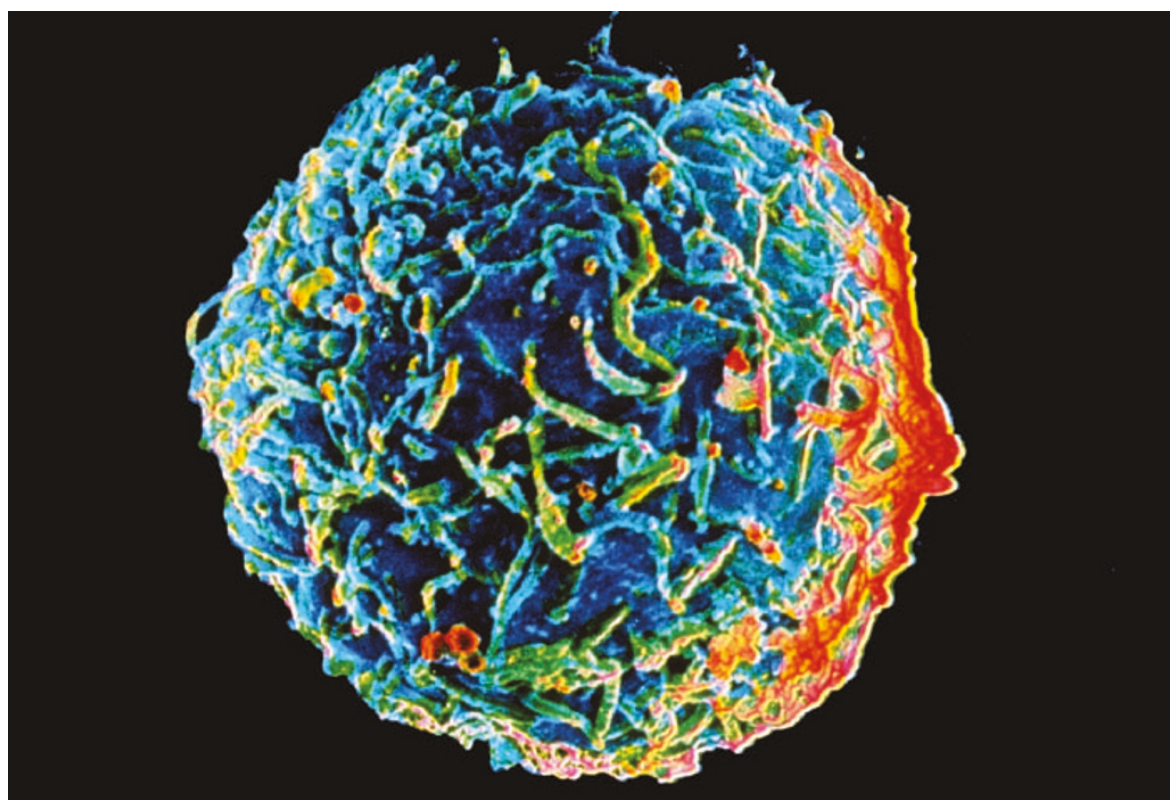

Can cancer drugs that attack B cells (above) also help to treat conditions such as rheumatoid arthritis?

\title{
Mouse opens door for study of autoimmune diseases
}

\section{Erika Check, Washington}

Biotechnology firm Genentech is pinning its hopes on a mouse model, in a bid to broaden the use of a billion-dollar cancer drug.

The company, based in South San Francisco, makes the drug Rituxan, which is used to treat non-Hodgkin's lymphoma. But clinical trials have suggested that the drug may also alleviate symptoms of autoimmune diseases, in which the immune system attacks the body's own cells. To test this idea, the company has created a mouse model that it says could speed up research on such diseases.

Rituxan works by targeting a specific protein carried on the surface of B cells, which form part of the body's immune response. By latching on to these cells it marks them for destruction, in the process clearing cancerous cells from the body. Genentech's new mouse model expresses the human B-cell protein recognized by Rituxan.

The model was announced on 19 April by Andrew Chan, Genentech's vice-president for immunology research, at the Federation of American Societies for Experimental Biology meeting in Washington DC. Scientists say that it could help fill a need for research on whether 'depletion therapies', such as Rituxan, can safely help patients with autoimmune diseases, by lending insight into the drugs' action. So far, many such therapies have yielded disappointing results in the clinic, but researchers hope that the new model could help to break that pattern.

"The preclinical models for depletion were really centred around cancer," says Edward Clark, an immunologist at the
University of Washington in Seattle. "We need good preclinical models to study these treatments in autoimmune diseases as well."

Chan told the meeting that the model has already been used to investigate key safety issues. For instance, clinical trials suggest that Rituxan eases symptoms of the autoimmune disease rheumatoid arthritis, in which the body destroys its own joints. But scientists had been puzzled by the fact that Rituxan does not seem to cause serious infections in the arthritis sufferers, even though it depletes their immune system of B cells.

Genentech scientists found that in mice some types of B cells survived the Rituxan treatment. Chan and his co-workers speculate that the drug kills only certain classes of $B$ cell, leaving others behind to fight off disease. "Maybe this is why the arthritis patients keep fairly intact immune systems," Chan says.

The finding might also have implications for how long and how well the drug works. Genentech is investigating such issues in a large clinical trial of Rituxan in rheumatoid arthritis patients. It is also testing Rituxan in patients with another autoimmune disease, called systemic lupus erythematosus.

Like many autoimmune diseases, lupus is poorly understood and difficult to treat. Clark, who has worked as a paid consultant to Genentech in the past, says that the new model could help answer questions that have held back this research, such as why depletion therapies only work in some autoimmune diseases, and whether the drugs can be made to work better. 